Primljen / Received: 2.8.2016. Ispravljen / Corrected: 9.12.2016.

Prihvaćen / Accepted: 11.1.2017. Dostupno online / Available online: 10.6.2017.

\section{The need and benefit of slab track: case of Lithuania}

Authors:

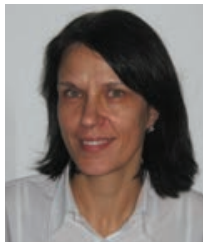

Inesa Gailienè, PhD. CE

Vilnius Gediminas Technical University Vilnius, Lithuania

inesa.gailiene@vgtu.It

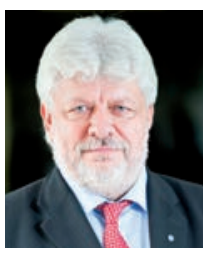

Prof. Alfredas Laurinavičius, PhD. CE Vilnius Gediminas Technical University Vilnius, Lithuania alfredas.laurinavicius@vgtu.It
Inesa Gailienè, Alfredas Laurinavičius

Professional paper

\section{The need and benefit of slab track: case of Lithuania}

Slab track structures have been used in the world for several decades now. However, the ballasted track is still much more popular compared to slab track structures, which is primarily due to its lower price. This article reviews and analyses development of slab tracks, with their advantages and disadvantages. Based on conditions prevailing on Lithuanian railways, the paper also distinguishes cases in which slab track structures could be of benefit, both economically and technologically. The decision-making system that would help make the right choice at the initial stage of structural design is also presented.

Key words:

slab track (ballastless track), ballasted track, railway track, new structure, track renewal

Stručni rad

Inesa Gailienè, Alfredas Laurinavičius

\section{Potreba i prednost primjene kolosijeka na čvrstoj podlozi: primjer Litve}

Kolosijeci na čvrstoj podlozi se već nekoliko desetljeća koriste u svijetu. No kolosijeci sa zastornom prizmom su još uvijek mnogo popularniji, prije svega je to predodređeno nižim cijenama. U radu su dani pregled i analiza razvoja kolosijeka na čvrstoj podlozi, uključujući njihove prednosti i nedostatke. Rad također ističe i slučajeve, temeljene na zahtjevima Litvanskih željeznica, u kojima bi primjena kolosijeka na čvrstim podlogama mogla donijeti ekonomske i tehničke prednosti. Prikazan je i sustav odlučivanja koji bi pomogao u ispravnom odabiru konstrukcije u početnoj fazi projektiranja.

Ključne riječi:

kolosijek na čvrstoj podlozi, kolosijek sa zastornom prizmom, nova konstrukcija, obnova kolosijeka

Fachbericht

Inesa Gailienè, Alfredas Laurinavičius

\section{Bedarf und Vorteile der Anwendung fester Schienenfahrbahnen: Beispiel Litauen}

Feste Schienenfahrbahnen kommen weltweit bereits seit einigen Jahrzehnten zur Anwendung. Gleise mit Bettungskörper sind dennoch bedeutend stärker verbreitet, insbesondere aufgrund der niedrigeren Kosten. In dieser Arbeit werden eine Übersicht und Analyse der Entwicklung fester Schienenfahrbahnen einschließlich ihrer Vor- und Nachteile gegeben. Ebenso werden basierend auf den Anforderungen litauischer Eisenbahnen Fälle erläutert, für die eine Anwendung fester Schienenfahrbahnen finanzielle und technische Vorteile erbringen könnte. Ein Entscheidungssystem zur Unterstützung der Auswahl entsprechender Konstruktionen in der anfänglichen Projektierungsphase wird dargestellt.

Schlüsselwörter:

feste Schienenfahrbahn, Schienen mit Bettungskörper, neue Konstruktion, Schienenerneuerung, Entscheidungssystem 


\section{Introduction}

Over the past 50 years, many different slab track structures have been manufactured and developed in different countries of the world. The decision to design and lay ballastless track is more often made with regard to high-speed railways, especially in China, Japan, and South Korea. However, even after deciding to lay the slab track, the abundance of possible slab track structures already poses some problems to the designers, railway managers and operators, as it becomes highly complicated to choose the most appropriate structure. Moreover, the cost of installing a slab track is much higher than that of a ballasted track. Therefore, the decision to opt for such construction should not be made before evaluating advantages, disadvantages, conditions and limitations of use, operating conditions, repair possibilities, and many other factors. It is also important to consider the life cycle cost (LCC) because the slab track structure will always be more expensive than the ballasted one when evaluating the initial installation costs only. However, after evaluating and comparing maintenance costs of the slab track and ballasted track, the situation may sometimes change quite drastically, especially as the maintenance of ballastless track is less expensive. Moreover, on railway lines characterized by great intensity, maintenance and repair activities are complicated to plan and organise. Operation stops, which are needed to enable repair work, are difficult to anticipate in case of an intensive train operation schedule. Nevertheless, research activities are under way to develop a model for a thorough LCC analysis that would make it easier to choose between ballastless and ballasted track structures [1, 2]. According to S.Tayabji, [3] "for slab track to be selected for new track construction or track renewal, the following requirements must be met:

- the slab track system must be capable of being constructed using a combination of existing track concrete pavement construction technologies

- the fastener system must be economical to install, it must have adequate strength and a long service life; the slab track must be practical to maintain and repair

- the life cycle cost of the slab track system must be equal to or lower than that of the conventional ballasted track.

Hence, when attempting to design a slab track structure, requirements must be established for the base, slab track elements, noise levels, and many other aspects. An appropriate calculation method, such as the Finite Element Method (FEM) etc., is often used to achieve the mentioned goals [4-6]. Fröidh, [7] uses the HSLdim model in his work. The HSLdim model is a framework for the optimisation of design speed. To calculate an optimum design speed, a model based on structure costs, operational costs, and attainable benefits, has to be established. In some cases researchers simply investigate possibilities of a specific structure [8], while sometimes possibilities in a specific region $[7,9,10]$ or for specific structures, such as bridges, are investigated $[5,11]$.
Based on research conducted in this field, and experience gained is some countries on the use of slab tracks, it is obvious that slab tracks may effectively be used in some cases, on some projects, under certain conditions, and for fulfilling specific requirements. Several interesting and important studies related to the use of slab tracks have also been conducted. Some of the most important ones are specified below [12-5]:

- UIC conducted the study of slab track possibilities in 2002. The study discusses differences between the slab track and ballasted track, as well as design conceptions and specific problems that are encountered when using slab tracks on embankments, bridges and in tunnels. Various slab track structures are examined in this study.

- In 2002 UIC prepared recommendations for the design of slab tracks and for estimation of slab track costs. The main goal of these recommendations was to help in estimating and designing structures using different Eurocodes and other standards, by indicating application areas and connections between different rules. The recommendations also include the elements that are insufficiently described in the standards.

- The "Innotrack" project (Innovative Track systems) was created to help in making an economically effective and high-quality railway infrastructure. The project also aimed at offering innovative solutions and reducing the costs of investment and infrastructure maintenance. The project consisted of several parts:

- railway support structure maintenance

- railway intersections and joints

- track and welding

- logistics of track maintenance and reconstruction. The mentioned project analysed the structures of BB ERS and the two-layer metal track construction mentioned in this sub-section (www.innotrack.net).

However, considering the fact that not many countries have the experience in using slab tracks, there is currently no standard and legal basis for the design, construction, and maintenance of slab tracks, while requirements for the use of slab tracks are also lacking. The decision making regarding the use and possibilities of slab tracks is often postponed or simply avoided. Hence, this method is not included among possible technical solutions. The countries in which the use of slab tracks is already a reality carry out various projects related to the research of construction possibilities in this field. Test strips are also mounted and more than one slab track structure are often laid in the tracks in order to evaluate their advantages, disadvantages and operating conditions. Such test strips have so far been implemented in Germany, France, Russia, and the USA. Therefore, it can be concluded that a decision system of a recommendatory nature should be developed in the first step. The system would enable determination of possibilities for using slab tracks, without a more detailed analysis. Certainly, further steps would be necessary to complement the initial study, i.e. to confirm the 
suitability of slab tracks in specific situations. For example: a system decision tree was created in Germany that made it more convenient to take several steps that lead "either directly to clear-cut statement or to the recommendation to perform a more detailed analysis" [15].

Various standards are used by Lithuanian Railways such as broad (Russian) standards and other standards for dual gauge railway lines, bridges, overpasses, tunnels, various-purpose stations and for the ice-free Port of Klaipeda. Intermodal terminals of Vilnius and Kaunas are currently being developed. This activity will provide better possibilities for further development of intermodal transport not only in Lithuania, but in the entire Baltic region as well. Hence, possible alternatives to a ballasted track are also investigated for such infrastructure, in order to ensure low maintenance costs, and proper durability, stability, and strength of structures. Moreover, a plan has been devised to build a European high-speed rail track Rail Baltica 2 in Lithuania. According to this plan, a standard gauge high-speed rail track Rail Baltica 2 is to connect Tallinn, Riga, Kaunas, Warsaw, and Berlin. Current infrastructure of Lithuanian railways, and the planned track route of Rail Baltica 2, are shown in Figure 1. It is precisely on high-speed railway lines that slab tracks are increasingly used for the entire line (not just for tunnels, bridges, level crossings, etc.), especially in Japan, China, Germany and other countries that are intensively developing high-speed railway networks. It is therefore important to properly assess the possibilities for using such structures in Lithuania as well. Currently, the main aims of infrastructure development are:

- raise speed limit, track capacity and highest allowed weight of freight trains

- reinforce track structure and improve design parameters;

- increase axle load

- flatten railway slopes and increase track curve radii

- electrify lines and optimise telecommunication systems and train operation management systems.
Slab tracks could prove to be a proper way to achieve most or at least some of these goals.

Several years ago, Lithuanian Railways decided to lay a slab track structure with the continuous track fastening at three level crossings. The slab track structure type Edilon LC-L was laid at these level crossings situated in Šiauliai County. Technical condition of the level crossings has been monitored in order to test and assess broader usability of such structures, and to gather information about maintenance costs, performance, etc. The comparison of level crossing costs for different structures is presented in Figure 2. The pie chart shows that more than a half of maintenance costs are incurred at level crossings with concrete panels. Meanwhile, the maintenance of slab track crossings constitutes only around $11 \%$ of all maintenance costs incurred for level crossings.

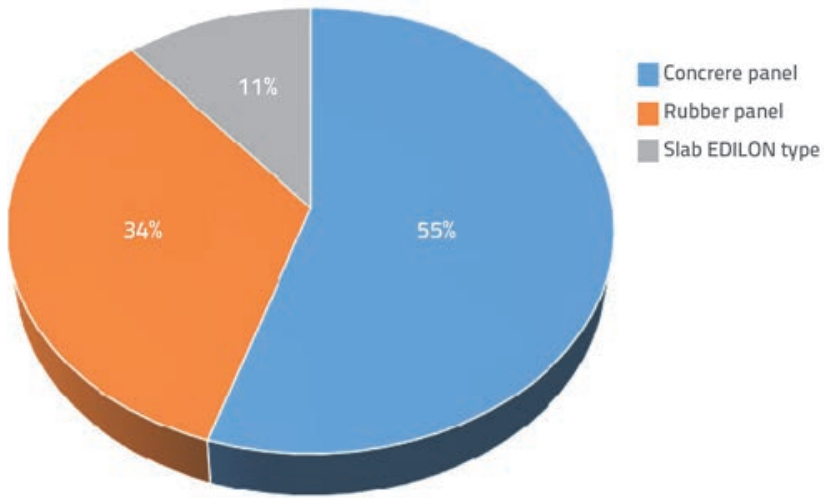

Figure 2. Distribution of maintenance costs at level crossings

This article first analyses development of slab track structures, examines their advantages and disadvantages, and provides an appropriate evaluation. Furthermore, an analysis and evaluation is carried out on facilities that could benefit from the use of slab track structures. The article also presents decision systems
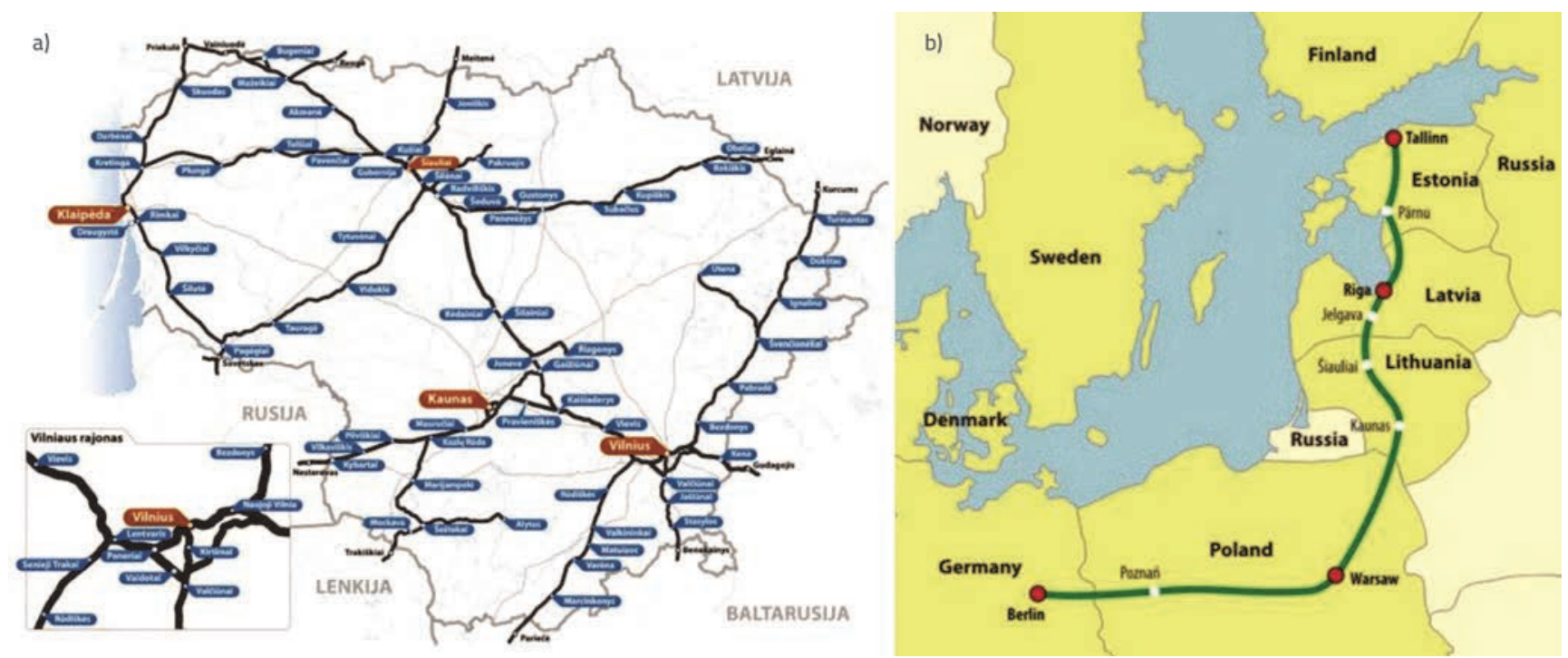

Figure 1. a) Lithuanian railway infrastructure; b) prospective track of Rail Baltica 2 transport corridor [16] 
for the first stage of decision making, i.e. before an in-depth analysis, in which initial answer is provided to the question: is it appropriate to carry out a more detailed analysis of a specific facility with regard to the use of the slab track structure? An example of the use of this decision system is also provided.

\section{Development of slab track structures: evaluation of advantages and disadvantages}

Many classifications of available slab track structures can be applied. However, essential construction principles are the same - they differ only slightly and insignificantly. On the other hand, fundamental extension or change of classification is possible in case of creation of new structures. In principle, all slab track structures are divided into "single-track fastening at different points" and "continuous track fastening" [1, 6, 9, 10, 15]. This classification may be extended by adding a third group of structures that are currently going through the design and creation process. One example is the NBT system that is currently being implemented in France. The classification according to fastening system is only one of several possible classifications.

\subsection{On supporting points (with or without sleeper)}

The structures that have railway sleepers may simply be laid onto the concrete or asphalt layer and attached. Railway sleepers may be laid onto a continuous slab or installed in it. Examples of such structures are "Sonneville" or "Stedef", Figure 3. For instance, the "Stefed" structure was implemented in France in 1970. The improved version of the first structure, "Sateba S312", was mounted in 2001 in the Marseilles Tunnel forming part of a TGV line. The speed of trains on this line reached $230 \mathrm{~km} / \mathrm{h}$, and the axle load was $175 \mathrm{kN}$. The "Sonneville" structure has been used in the Eurotunnel since 1996. Here, the train speed is up to 160 $\mathrm{km} / \mathrm{h}$, and the axle load is $225 \mathrm{kN}$. In addition, a track with this type of structure is operated in Austria (1992, $230 \mathrm{~km} / \mathrm{h}, 250$ kN) and Switzerland (160 km/h, 225 kN/per axis) since 1995 [1].

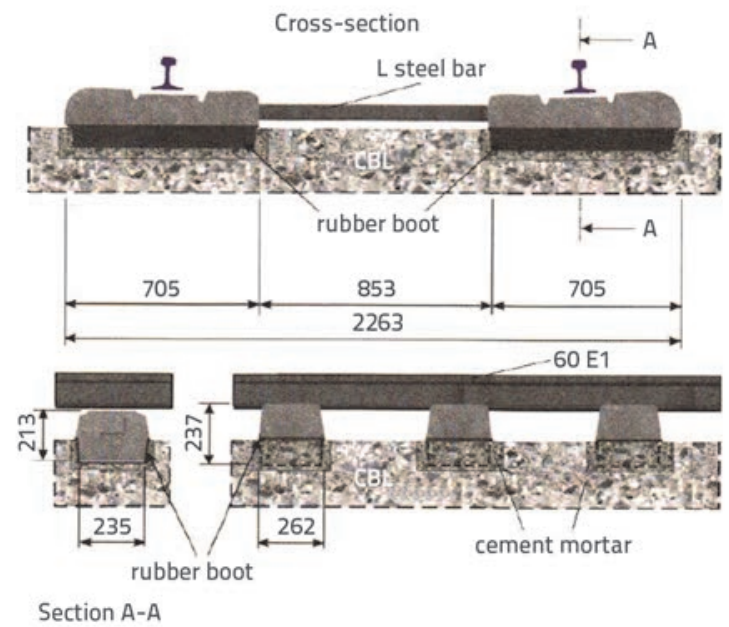

Figure 3. "Stedef" slab track structure, dimension in [mm]
Most recent improvements of this structure were implemented by making a $2 \mathrm{~km}$ test split at "TGV East-European" in France.

During the development phase, the structures were built with railway sleepers or blocks mounted in the continuous concrete slab and the proper geometry of the track was ensured by means of a fastening system. Using this principle, the noise and vibration in the structure was reduced using appropriate mass-spring systems (elastic elements for reducing vibration and noise). Such slab track structures are sometimes referred to as compact structures because they are of low height $(472 \mathrm{~mm}$ from the slab base to railhead). Based on this principle, the "Rheda" structure (later known as "Rheda 2000") was created (Figure 4). Other structures made according to this principle are "Züblin" structures (di-block sleepers mounted directly on concrete, laid in soft concrete).

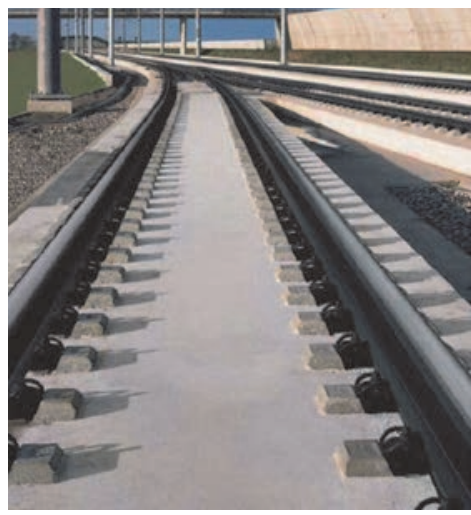

Figure 4. Slab track structure "Rheda 2000"

The mentioned structures were further optimised by developing the idea that makes use of pre-fabricated concrete slabs. This idea seemed more attractive than the continuous concreting of the slab track. Historically, the first blocks with the JSLAB structure ("Shinkansen" system) were created by the Japanese. JSLAB was installed in Japan at lines spanning over 1,000 km, as well as in South Korea and Taiwan (2007).

Other pre-fabricated slab structures are "ÖBB-Porr" (made in Austria) and "Bögl" (made in Germany and shown in Figure 5).

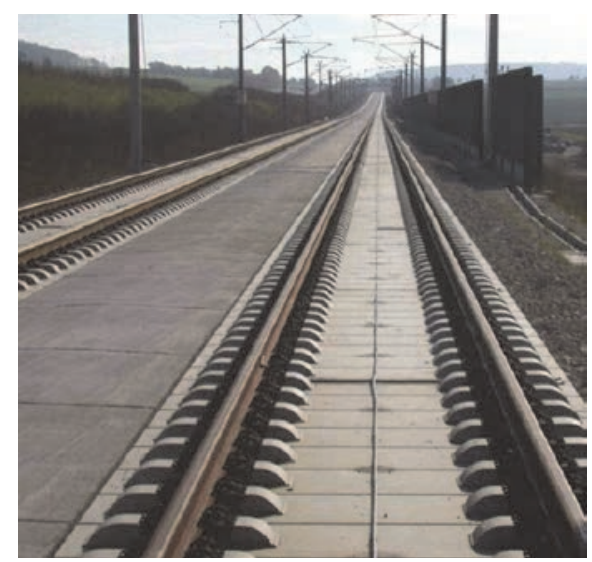

Figure 5. Slab track structure "Bögl" (railway line NürnbergIngolstadt, 2006) 
The first slab was laid in 1992 at test strips and, since 1996, at real railway segments, mostly in tunnels, and later on in the Lehrter Railway Station in Berlin (Lehrter Bahnhof). In 2006, the "Bögl" structure was used at the railway line Nürnberg-Ingolstadt (Figure 5). This structure was also used in China in 2008 at the Beijing-Tianjin line $120 \mathrm{~km}$ in length. Further changes and development of slab track structures were made in China and Korea. Two assemblable slab track structures were developed in Korea and, after carrying out fatigue test, they were mounted in two strips.

\subsection{Continuous support}

A different solution for slab track structures, but the principle is similar to that of a tram. In these structures, the railway is mounted (fixed) in the elastomeric layer. An example of such a structure is an embedded rail system produced by Edilon) (Sedra, installed in the Netherlands, on concrete bridges (1976-2005) and metal bridges (1994-2004). Operating speeds on these tracks were $140 \mathrm{~km} / \mathrm{h}$, and the axle load was $225 \mathrm{kN}$. This structure was later used in a tunnel in Spain and in a high-speed train line in Madrid between the stations of Chamartín and Atocha (cf. Figure 6).

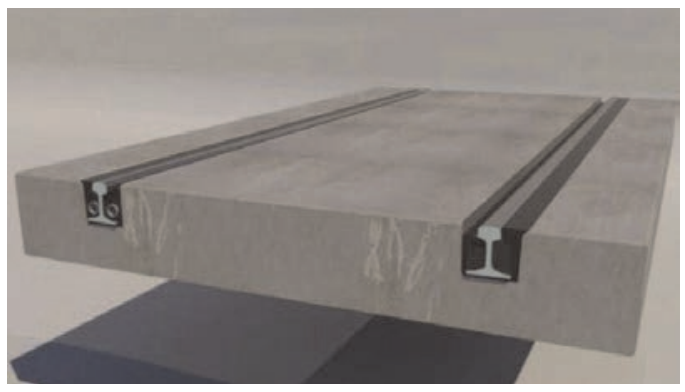

Figure 6. ERS (embedded rail system) slab track structure

This concept of fixed railways was developed more radically by "Balfour Beatty" (an international infrastructure group that funds, develops, promotes, and monitors infrastructure structures). The concept was named BB ERS. In this structure, the cross-section of the fixed rail was simplified into a rectangle [17] (Figure 7).

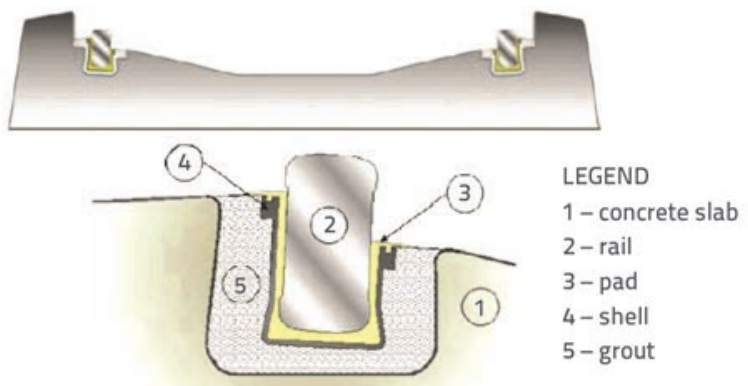

Figure 7. BBERS (Balfour Beatty embedded rail system) slab track structure
Finally, another structure should be mentioned, i.e. a two layer steel track system [13] in which metal railway sleepers are laid on a metal beam, and the entire system lies on the concrete bearing layer with individual support points. With this system, a smaller amount of stress is transferred to the lower layers of the structure, and there is less vibration compared to the ballasted railway. Due to its high price, the use of this structure should be restricted to switches only (Figure 8).

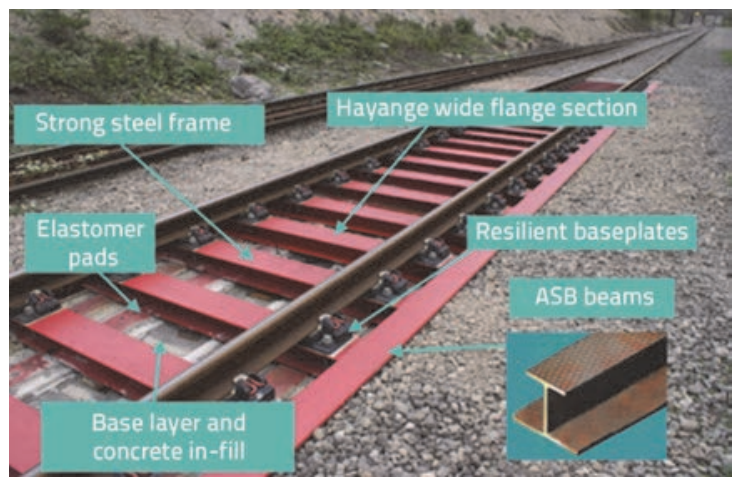

Figure 8. Two-layer metal track system

\subsection{Latest tendencies in slab track development}

A project called "New Ballastless Track" (NBT) was implemented in France (2007-2013). Six French companies took part in the project: VCSA, RFF, "Ifsttar", "Railtech", CEF, "Alstom Transport". The organisers of the project specified several requirements for the ballastless track structure [18]:

- for many years, a lot of negative reviews on the operation of ballastless tracks have been related to the fragility of such tracks. The track is especially fragile in places where settlements (for instance, on a high embankment) or different settlements is noticeable (places where the ballasted track becomes ballastless or vice versa). Therefore, considering the mentioned drawbacks, an attempt was made to make a structure that would last 100 years. The main goal of the developers was to avoid any repair works during the entire lifetime of the structure;

- NBT was created for the train operating speed of up to 360 $\mathrm{km} / \mathrm{h}$ and lines with mixed traffic with the axle load of 250 $\mathrm{kN}$;

- the structure that may be used in switches and crossings is created;

- the mounting time of the structure must be 1000 m a day;

- return on investment must be 10-25 years.

The structure was mounted in a railway strip. The skewer and one transition from the slab track to the ballasted track is monitored and studied. Since the operation and monitoring of the structure has started only recently, these are the main studies of its parameters, condition and indicators. Monitoring activities are in progress. 
The principal scheme of the structure created in the NBT project is presented in Figure 9.

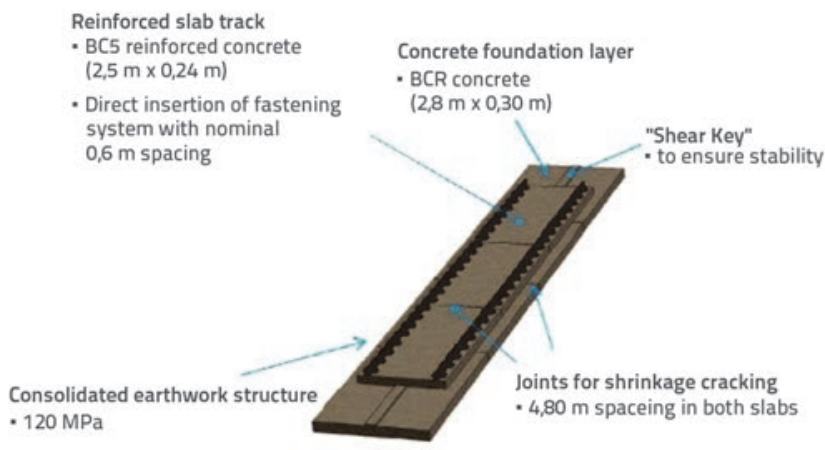

Figure 9. Principle NBT scheme

As can be seen from development analysis, there is a wide variety of slab track structures. Hence, it is difficult for the designers and the managers to understand how they differ from one another, and to analyse their advantages and disadvantages. Therefore, a more detailed LCC analysis is necessary for making a proper decision on the use of a particular slab track structure. As already mentioned, the LCC analysis is a separate and complicated task. However, sometimes it is important to answer the question that should be asked at the initial stage - can a ballastless structure prove beneficial for a specific facility under specific conditions? In case the answer is negative, money is saved and time is used for a more detailed analysis.
To be able to answer this question, it is first of all important to record the pros and cons of a slab track structure. After analysis of many published research results $[6,10,19,20]$, a comparative analysis is made for ballasted and ballastless track structures, according to various structural characteristics and indicators, as shown in Table 1.

In conjunction with the data given in Table 1, and based on results of various studies and experience gained in other countries, the following preconditions (assumptions) are recommended for establishment of slab track systems in Lithuania:

1. It must be ensured that the speed of trains will not be lower than the speed established at specific railway lines (in case of mixed traffic lines, not lower than $160 \mathrm{~km} / \mathrm{h}$, and in case of high-speed train lines $-250 \mathrm{~km} / \mathrm{h}$ ).

2. It must be ensured that the structure will withstand axle loads not lower than $25 \mathrm{t}$ at mixed traffic lines, and $22.5 \mathrm{t}$ at high-speed lines.

3. It must be ensured that the established width of the track is maintained.

4. If the structure is used in a tunnel, it must be ensured that road traffic can pass over it.

5. Appropriate noise and vibration emission measures must be implemented and, if needed, relevant mitigation measures must be applied.

6. The cost of structure may not exceed the cost of ballasted track by more than $30-50 \%$.

\section{Table 1. Comparative analysis of track structures}

\begin{tabular}{|c|c|c|}
\hline Structure features/indicator & Ballasted track & Slab track \\
\hline Longer time needed to fix defects and perform repair work & + & \\
\hline Lower capital investments for construction work & + & \\
\hline Lower costs for track maintenance and easier maintenance & & + \\
\hline Possibility to adjust geometric parameters & + & \\
\hline Speed of track restoration after a derailment or catastrophe & + & \\
\hline Emission of noise and vibration & + & \\
\hline Unification for various operating conditions & + & \\
\hline Better durability & & + \\
\hline Possibility for motor vehicles to pass over the tracks & & + \\
\hline Vegetation destruction and dustiness & & + \\
\hline $\begin{array}{l}\text { Mounting the track at places with weak base and high ground water } \\
\text { level }\end{array}$ & + & \\
\hline Enough expertise in operating the structure, awareness of its decay & + & \\
\hline $\begin{array}{l}\text { Possibility to design curves of a lower diameter, higher rises and } \\
\text { shorten the length of the track (if track layout may be adjusted) }\end{array}$ & & + \\
\hline Stability of the structure & & + \\
\hline
\end{tabular}


7. The efficiency of construction works must not be lower than 500-800 m a day.

8 The following must be provided: methodology for assessing technical conditions with appropriate scheduling of assessment activities, as well as the technology, measures and equipment for performing repair and maintenance works.

9 The requirements for preparing the base on which the slab structure will be laid must be established.

10. Return on investment of less than 20 years must be specified.

\section{Analysis and evaluation of possibilities for slab track use on Lithuanian railway network}

According to extensive analysis and research results, the following structures (hereinafter - exclusive structures), may ensure economical, technological and otherwise efficient operation of a slab track structure:

- Tunnels

- Bridges

- Level Crossings

- Overpasses

- Certain yards of embankments or stations, terminals of logistics centres

- High speed railway lines.

On the other hand, a lot of research results and evaluations show that it is not economically effective to lay slab track structures on mixed traffic lines and on embankments.

The infrastructure of Lithuanian railways is further analysed with the focus on exclusive structures. At the present time, the total length of railways in Lithuania amounts to $1,676 \mathrm{~km}$. There is one tunnel, 385 bridges (140 of them are average sized or big bridges with the length of less than $25 \mathrm{~m}$ ), 523 crossings, and

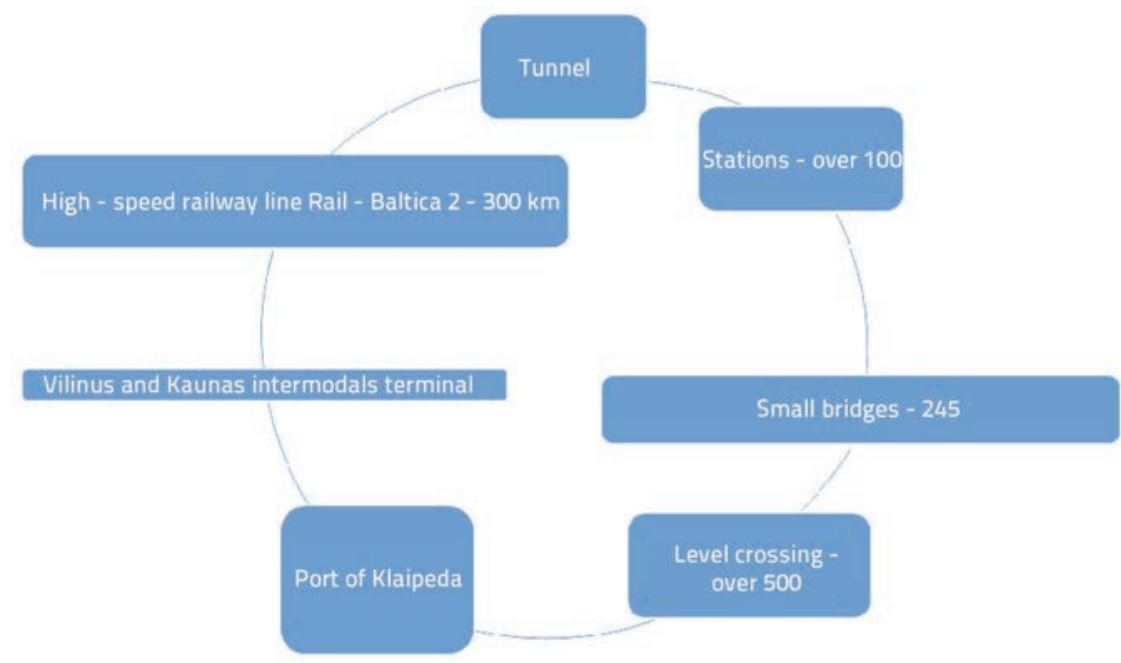

Figure 10. Possibilities of slab track use for exclusive structures within infrastructure of Lithuanian Railways
43 overpasses (Figure 10). Major loading and materials handling works are currently undertaken at the sea port of Klaipeda. In addition, there are more than one hundred railway stations for various uses (commercial, distribution, border, etc.) in the country. Construction of a high-speed train line - Rail Baltica 2 (with around $300 \mathrm{~km}$ in the territory of Lithuania) is currently planned. Various repair works are carried out annually on railways in order to improve technical parameters of Lithuanian railway tracks and to ensure safe traffic. For instance, in 2014 one bridge was reconstructed, one bridge was renewed, 11 crossings were renewed, $71.5 \mathrm{~km}$ railway tracks were renewed, and $27.5 \mathrm{~km}$ of existing tracks were reconstructed.

In addition, there are some structures within the Lithuanian ballast railways in which a series of maintenance problems arise during operation of the ballast track structure. After conducting a survey with Lithuanian railway managers, it was found that the following problems are often encountered:

- Level crossings: because of wearing panels, frequent asphalting of roadways next to level crossings, and obvious settlement of track under level-crossing panels.

- Bridges: if they are in a territory where bridge demolition is prohibited, the bridges are old and their width is insufficient for installing the ballast prism that complies with official standards.

- Tunnel: without the Russian gauge track, it is also planned to have a standard gauge track, which would use a slab track structure in order to require less maintenance and enable road traffic.

- Port yard railways: that do not permit operation of road traffic.

During the operation of these diverse structures and, also, while planning to operate a high-speed line, it is important to know and properly evaluate the alternative to a ballasted track - a slab track. It is also important to define what facilities could benefit from the use of such track structures. First, an initial analysis should be conducted using the decision system that would enable evaluating the pros and cons of a slab track, fulfilment of preconditions, exclusion criteria, etc. Then it should be determined in which way to conduct a more accurate LCC analysis. In this way, preconditions would be created in Lithuania to write a normative legal documentation in order to legalise the design, construction, technical specifications, maintenance and repair rules for slab tracks, etc.

Based on the analysis made for exclusive structures, which was aimed at determining which slab track structure may be operated and would prove beneficial, two decision systems have been compiled: "SP-1" and "SP-2" (Figures 11 and 12). Prior to the stage 
Decision support system in case of repair or reconstructed exclusive objects

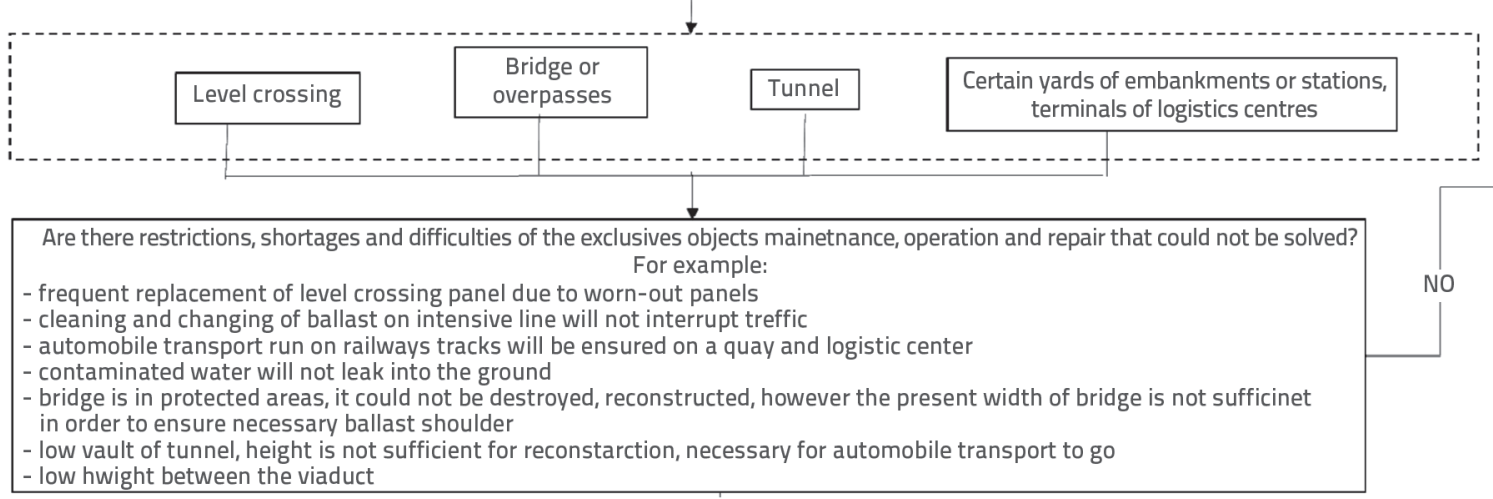

YES

Is it possible solve problems that are idnetified in ballasted track exclusives object taking into account advantages of slab track and constructive solution?

YES

$\checkmark$

Results of detailed ballast and slab track LCC analysis show that it is appropriate to use slab track:

- the capital costs of construction and road-laying

- preparation of the land or building for laying of slab path

- maintenance costs

- costs due to operation interfence

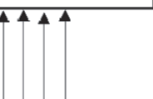

NO

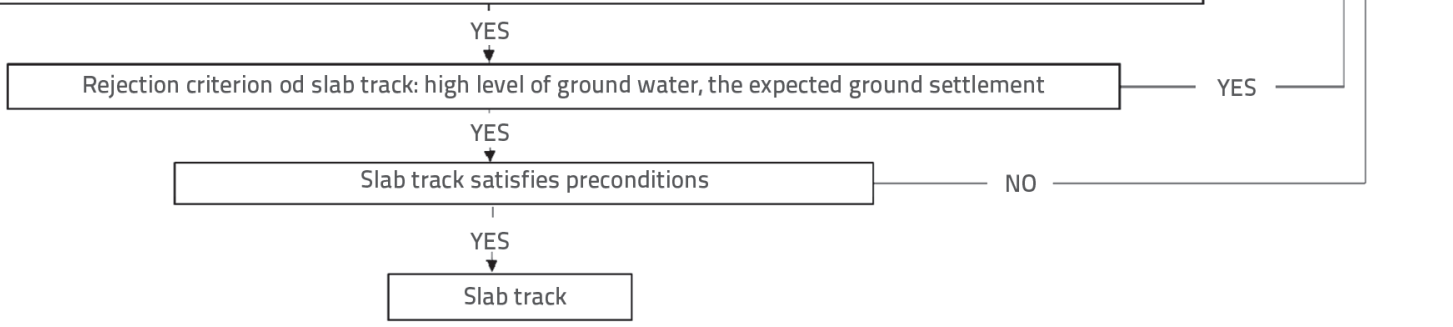

Figure 11. Decision system SP-1

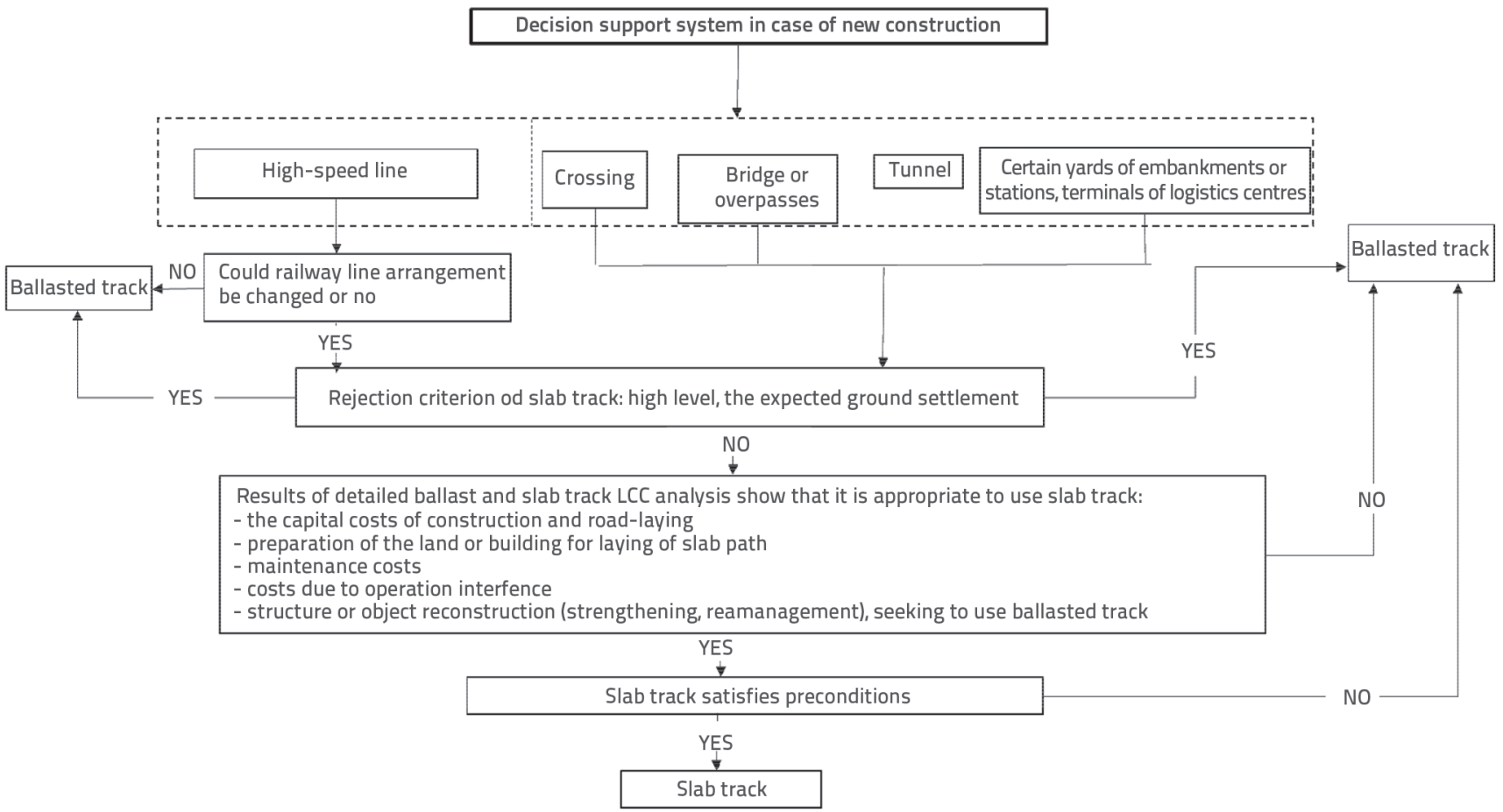

Figure 12. Decision system SP-2 
of detailed analysis, these systems could aid in answering the question of whether it would be beneficial to design a slab track structure in specific cases.

The assumption in compiling SP-1 and SP- 2 is that in the design of a new linear slab track structure it may be effective to lay it at high-speed lines and exclusive structures, in which case the slab track structure would be more effective than the ballasted track structure. On the other hand, in the repaired or reconstructed exclusive structures, the possibility of laying slab track structures should be considered only if the operated ballasted track structure or its operating conditions (intensity of defect accumulation, need for maintenance, etc.) are insufficient.

The decision system SP-1 provided in Figure 11 is designed to answer the following question: is it appropriate to design a slab track structure in the repaired or reconstructed exclusive structures at mixed traffic railway lines?

The decision system SP-2 provided in Figure 12 is designed to answer the following question: is it appropriate to design a slab track structure for the construction of new high-speed lines and/or newly designed exclusive structures within the railway infrastructure at mixed traffic railway lines?

\section{Concluion}

The research conducted is most often related to some qualities or operating conditions of the slab track structure or its elements, and it is most often focused on a narrow area of study, e.g. design of a slab track on metal bridges. After an appropriate research, it was established that there is a lack of information on the possibilities of considering slab track structures at the initial pre-design stage. An effective method to help answer the question of choosing a structure at an initial stage of planning is to make use of decision systems that help answer the following question: is it appropriate to use the slab track structure, or is it necessary to carry out a more detailed analysis in order to make this decision. We consider that systems of this kind are useful, especially when they are applied to a specific railway network with specific technical and operating features.

After analysis, it was established that slab track structures would be most beneficial on Lithuanian railways at: tunnels, bridges, crossings, overpasses, embankments or certain station yards, and terminals of logistics centres. Following analysis of Lithuanian railways, it was also established that another possibility for slab track use is the standard gauge high-speed railway line Rail Baltica 2 (which is not yet being realised).

In order to make the decision regarding the use of a slab track, it is suggested to begin the decision-making by defining and distinguishing whether is it a new construction or a repaired (or reconstructed) facility. Therefore, two systems - SP-1 and SP-2 - have been created in order to determine, based on several simple questions, which railway construction method would be inappropriate for specific conditions, and in which cases a more detailed analysis should be conducted. Further research should focus on specifying a more thorough analysis that should lead to an exact estimation of LCC, which would constitute the basis for the decision on conducting an economic benefit analysis.

\section{REFERENCES}

[1] Gautier, P.E.: Slab Track: Review of existing systems and optimization potentials including very high speed, Construction and Building Material, 92 (2015) 12, pp. 9-15, https:// doi,org/10,1016/j,conbuildmat,2015,03,102

[2] Zoeteman, A.: Life cycle cost analysis for managing rail infrastructure, EJTIR, 1 (2001) 4, pp. 391-413,

[3] Tayabji, S.: Concrete slab track for freight and high speed service applications, A survey of practice, 2000,

[4] Blanco-Lorenzo, J., Santamaria, J., Vadillo, E.G., Oyarzabal, O.: Dynamic comparison of different types of slab tracks and ballasted track using a flexible track model, Proc, IMechE Part F: Journal of Rail and Rapid Transit, 225 (2011), pp. 574-592, https://doi.org/10.1177/0954409711401516

[5] Gillet, G.: Simply supported composite railway bridge: a comparison of ballasted and ballastless track alternatives, Sweden, KTH Architecture and the Built Environment, Master of Science Thesis, 2010,

[6] Michas, G.: Slab Track systems for high-speed railways, Master degree project, Royal Institute of Technology, Stockholm, Sweden, pp. 95, 2012.
[7] Fröidh, O.: Design speed for new high-speed lines, Journal of Rail Transport Planning \& Management, 4 (2014) 3, pp. 59-69, https:// doi.org/10.1016/j.jrtpm.2014.09.002

[8] Freudenstein, S.: RHEDA 2000: ballastless track systems for high-speed rail applications, International Journal of Pavement Engineering, 11 (2010) 4, pp. 293-300, https://doi. org/10.1080/10298431003749774

[9] Pichler, D., Fenskem, J.: Ballastless track systems experiences gained in Austria and Germany, Railway interchange 2013, AREMA annual conference, Indianapolis, pp. 81-100, 2013.

[10] Ižvolt, L., Šmalo, M.: Historical development and applications of unconventional structure of railway superstructure of the railway infrastructure of the Slovak Republic, 10 (2014) 1, pp. 78-93, https://doi.org/10.2478/cee-2014-0010

[11] Serdelova, K., Vican, J.: Analysis and design of steel bridges with ballastless track, XXIV R-S-P seminar, Theoretical Foundation of Civil Engineering, Procedia Engineering, 111 (2015), pp. 702 708, https://doi.org/10.1016/j.proeng.2015.07.135

[12] UIC recommendations for Design and calculation of ballastless track, 2008. 
[13] http://www,transport-research,info/project/innovative-tracksystems

[14] Feasibility study "Ballastless track", UIC infrastructure Commision Civil Engineering Support Group (13), 2002.

[15] Koriath, $H_{\text {, }}$ Hamprecht $A_{\text {, }}$ Huesmann, $H_{1}$, Ablinger, $P_{\text {, }}$ Bringing Objectivity into system decisions between ballasted track and slab track at Deutsche Bahn, http://www, plassertheurer,com/pdf/ publications/rtr_0302,pdf,

[16] http://www,baltictransportjournal,com/overland-rail-road/railbaltica-joint-venture-in-place, 1804,html
[17] Esveld, C.: Recent developments in high-speed track, keynote lecture on $1^{\text {st }}$ International Conference on Road and Rail Infrastructure - CETRA 2010 (ed. Lakusic, S.), pp. 19-28, 17-18 May 2010, Opatija, Croatia, http://www,esveld,com/Download/ RAILPROF/Papers/Esveld\%20RECENT\%20DEVELOPMENTS\%20 IN\%2OHIGH,pdf

[18] Robetson, I., Masson, C., Sedran, T., Barresi, F., Caillau, J., Keseljevic, C., Vanzenberg, J.M.: Advantages of a new ballastless trackform, Construction and building material, 92 (2015), pp. 16-22.

[19] Sugrue, W.: Permanent way for high speed lines, $9^{\text {th }}$ Training on high speed systems, UIC-Paris, 2013.

[20] Lechner, B.: Railway concrete pavements, $2^{\text {nd }}$ international conference of best practices for concrete pavements, Florianapolis, 5 (2011). 